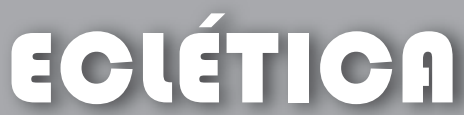 química
}

\section{TITRIMETRIC AND SPECTROPHOTOMETRIC ASSAY OF BUPROPION HYDROCHLORIDE IN PHARMACEUTICALS USING MERCURY(II) NITRATE}

\author{
M. A. Sameer Abdulaziz, K. Basavaiah* and K. B. Vinay \\ Department of Chemistry, University of Mysore, Manasagangotri, Mysore-570006, India \\ *Email: basavaiahk@yahoo.co.in
}

\begin{abstract}
Two simple, rapid and accurate methods for the determination of bupropion hydrochloride (BUP) in pure and in pharmaceutical preparations are described. Both methods are based on the measurement of the chloride of its hydrochloride. In the titrimetric method, the chloride content of bupropion hydrochloride is determined by titrating with mercury(II)nitrate using diphenylcarbazone-bromophenol blue as indicator. Titrimetric method is applicable over a range $2-20 \mathrm{mg}$ of BUP and the reaction stoichiometry is found to be 2:1 (BUP: $\left.\mathrm{Hg}\left(\mathrm{NO}_{3}\right)_{2}\right)$. The spectrophotometric method involves the addition of a measured excess of mercury(II) nitrate reagent in formate buffer to the drug, and after ensuring the reaction had gone to completion, the unreacted mercury(II) is treated with a fixed amount of diphenylcarbazone, and absorbance measured at $515 \mathrm{~nm}$. The absorbance is found to decrease linearly with increasing concentration of BUP and the calibration curve is linear over $1.0-15.0 \mu \mathrm{g} \mathrm{mL} \mathrm{m}^{-1} \mathrm{BUP}$. The proposed methods were successfully applied to the determination of BUP in commercially available dosage forms with good accuracy and precision, and without detectable interference by excipients. The accuracy was further ascertained by placebo blank and synthetic mixture analyses and also by recovery experiments via standard-addition procedure.
\end{abstract}

Keywords: titrimetry; spectrophotometry; bupropion hydrochloride; mercury(II)nitrate; diphenylcarbazone.

\section{Introduction}

Bupropion hydrochloride (BUP), chemically known as 1-(3-chlorophenyl)-2-[(1, 1-dimethylethyl) amino]-1-propanone hydrochloride (Fig. 1) [1], is the water soluble salt of an aminoketone [2], with a pKa of 7.9 [3] and it is known also with the generic name of amfebutamone hydrochloride. Bupropion is structurally related to phenylethylamines, cathinone (a CNS stimulant from leaves of Catha edulis) and to the anorectic drug diethylpropion $[4,5]$. Bupropion is a second-generation antidepressant agent that is also used in the management of smoking cessation [6]. Since its introduction in 1989, the most extensive- ly used technique for the quantitation of BUP is HPLC but, most of the procedures using this technique are devoted to biological fluids like plasma $[7,8,9]$, plasma and serum [10] and dog plasma [11]. Even such techniques as radioimmunoassay [12], GC [13], LC [14, 15], LC/ESI/MS/MS [16], LC-MS [17] and LC-MS/MS [18, 19] are also confined to biological fluids including dog plasma [12], human plasma [13, 14, 15], waste water [16], rat everted gut sacs [17], plasma and urine [18] and human, mouse and rat plasma [19]. A limited number of methods have been reported for the quantitation of BUP in dosage forms. Methods based on several techniques such as non aqueous titration [20], HPLC [20, 21, 22], and GLC [23] 
are found in the literature for the determination of BUP in pure form and in tablets.

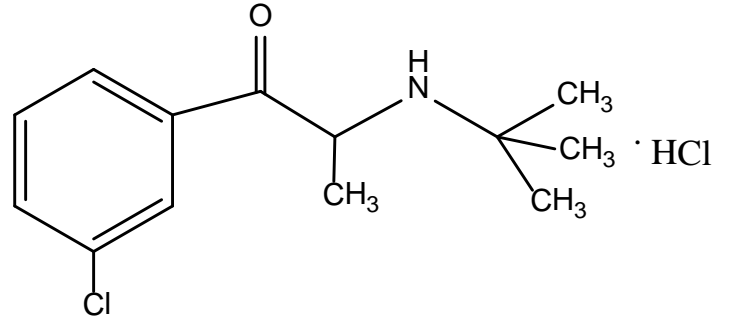

Figure 1. Structure of bupropion hydrochloride

There is only one report on the titrimetric [20] determination of BUP, which involves neutralization of the drug with perchloric acid in non aqueous medium. As per our literature survey, no visible spectrophotometric method has ever been reported for the determination of BUP in pharmaceuticals.

The purpose of this investigation was to develop simple, rapid, accurate and inexpensive procedures for the quantitation of BUP in pure form and in pharmaceutical formulations. The titrimetric procedure involves the titration of the chloride content of the hydrochloride of the drug in acidic condition with mercury(II) nitrate while the spectrophotometric method uses an indirect procedure based on the measurement of the decre-

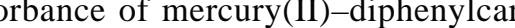
zone complex at $515 \mathrm{~nm}$ in acidic condition.

\section{Experimental details}

\section{Apparatus}

A Systronics model 106 digital spectrophoometer provi was used for all absorbance measurements.

Materials

Pharmaceutical grade bupropion hydrochloride (BUP) pure was received from GlaxoSmithKline Pharmaceuticals, Mumbai, India. The following phamatical purchased from commercial sources in the local market and subjected to analysis: Bupron-SR-150 from Sun pharmaceutical industries, jammu, India, and Ession-ER-150 from psycoremedies, ludhiana, Punjab, India.

\section{Reagents}

All the reagents used were of analytical-regent grade and double distilled water was used throughout the investigation.

Mercury(II) nitrate $\left(0.01 \mathrm{~mol} \mathrm{~L}^{-1}\right)$. Prepared by dissolving $1.713 \mathrm{~g}$ of the chemical (S.d fine-chem. Ltd., Mumbai, India) in distilled water and diluting to $500 \mathrm{~mL}$. The solution was standardized using pure potassium chloride [24]. The stock solution was diluted to $0.005 \mathrm{~mol} \mathrm{~L}^{-1}$ for stock so政 $\mathrm{mL}^{-1} \mathrm{Hg}(\mathrm{II})$ for the spectrophotometric work

Diphenylcarbazone-bromophenol blue mixed indicator for titrimetry. The mixed indicato was prepared by dissolving $0.25 \mathrm{~g}$ of diphenylcarbazone (The British Drug Houses LTD, Poole, England) and $0.025 \mathrm{~g}$ of bromophenol blue (LOBA Chemie PVT LTD, Mumbai, India) in $50 \mathrm{~mL}$ of ethanol.

Diphenylcarbazone for spectrophotometry $(0.02 \%)$. Prepared by dissolving $20 \mathrm{mg}$ of the regent in $15 \mathrm{~mL}$ of ethanol and diluting to $100 \mathrm{~mL}$ with distilled water.

Formate buffer. It was prepared by dissolving $0.52 \mathrm{~g}$ sodium formate (LOBA Chemie PVT LTD, Mumbai, India, assay $99.0 \%$ ) in $70 \mathrm{~mL}$ o distilled water, $\mathrm{pH}$ adjusted to 3.4 with $0.5 \mathrm{mo}$ $\mathrm{L}^{-1}$ nitric acid and finally diluted to $100 \mathrm{~mL}$ with water.

Nitric acid $\left(0.05 \mathrm{~mol} \mathrm{~L}^{-1}\right)$. Concentrated nitric acid (Merck, Mumbai, India; sp. gr. 1.41) was diluted appropriately with water to get 0.05 mol L ${ }^{-1}$

Gum Arabic (2\%). Prepared by dissolving $2 \mathrm{~g}$ of acacia (LOBA Chemie PVT LTD, Mumbai, India) in $100 \mathrm{~mL}$ of hot water and the solution was filtered when it is turbid.

Standard solution of bupropion hydrochloride. A stock standard solution equivalent to 2.0 $\mathrm{mg} \mathrm{mL}^{-1}$ of BUP was prepared by dissolving accurately weighed $200 \mathrm{mg}$ of pure drug in water and diluting to the mark in a $100 \mathrm{~mL}$ calibrated flask wer this solution was used in titrimetric work. The stock solution equivalent to $2000 \mu \mathrm{g}$
$\mathrm{mL}^{-1}$ of BUP was diluted appropriately with waer to get a working concentration of $100 \mu \mathrm{g} \mathrm{mL}$ BUP for use in spectrophotometric work.

\section{Assay Procedures}

Titrimetry. A $10 \mathrm{~mL}$ aliquot of the drug soution containing 2-20 mg BUP was transferred into a $100 \mathrm{~mL}$ conical flask and two drops of diphenylcarbazone-bromophenol blue mixed indicator were added. Nitric acid $\left(0.05 \mathrm{~mol} \mathrm{~L}^{-1}\right)$ was added dropwise to obtain the yellow color. The contents were then titrated by adding mercury(II) nitrate $\left(0.005 \mathrm{~mol} \mathrm{~L}^{-1}\right)$ slowly from a $10 \mathrm{~mL}$ burette with continuous stirring by a magnetic a whe-violet end-point. The dug content in the to a blue-violet end-point. The

$$
\operatorname{Amount}(m g)=\frac{V \times M w \times R}{0.5}
$$

where $\mathrm{V}=$ volume of mercury(II) nitrate consumed in $\mathrm{mL} ; \mathrm{Mw}=$ molecular weight of the drug and $\mathrm{R}=$ molarity of mercury(II) nitrate solution.

Spectrophotometry. Different aliquots of $\mathrm{mL}^{-1}$ ) were accurately transferred into a seies of $10 \mathrm{~mL}$ volumic flasks and the total volume was adjusted to $1.5 \mathrm{~mL}$ by adding requisite volume of water. Then, $1 \mathrm{~mL}$ of the formate buffer and five drops of gum arabic stabilizer $(2 \%)$ were added. To each flask was then added $2 \mathrm{~mL}$ of $50 \mathrm{~m} \mathrm{~mL}$ mercury(II) solution. The flasks were stoppered, the contents mixed well and allowed to stand for 10 min with occasional shaking. Finally, $2 \mathrm{~mL}$ of diphenylcarbazone reagent $(0.02 \%)$ was added to each flask, diluted to the mark with water, mixed each flask, dily the nark with water, mixed asured at $515 \mathrm{~nm}$.

Assay Procedure for Tablets. Ten tablets were weighed accurately and ground into a fin powder. An amount of the powder equivalent to $200 \mathrm{mg}$ of BUP was accurately weighed into $100 \mathrm{~mL}$ calibrated flask containing about $60 \mathrm{~mL}$ of water. The solution was shaken thoroughly for about $15 \mathrm{~min}$, diluted to the mark with water, an filtered using a Whatman No. 42 filter paper. First $10 \mathrm{~mL}$ portion of the fitrate was rejected and a
$\mathrm{mL}^{-1}$ BUP) was taken for assay by titrimetric procedure. Another convenient aliquot of filtrate (containing $2000 \mu \mathrm{g} \mathrm{mL}^{-1} \mathrm{BUP}$ ) was diluted with water to get $100 \mathrm{\mu g} \mathrm{mL}^{-1}$ of BUP for use in spectrophotometric method. Suitable aliquets we dures described earlier.

\section{Results and Discussio}

The proposed methods, in essence, are based on the determination of the chloride content of the bupropion hydrochloride.

\section{Method development}

Titrimetric method. In this procedure, the drug was determined by measuring its chloride content by titrating with mercury(II) nitrate using diphenylcarbazone-bromophenol blue as indicator to a blue-violet end-point [25]. This has served as a basis for the assay of many pharmaceuticals [26-29]. This principle is used in the determination of the BUP which ionizes in aqueous solution to give the chloride ion which can be titrated with mercuric ion (e.g., with a solution of mercury(II) nitrate acidified with nitric acid) as follow:

$$
2 \mathrm{Cl}^{-}+\mathrm{Hg}^{2+}
$$

This reaction is essentially stoichiometric, since slightly dissociated mercuric chloride produced. The end point may be detected with diphenylcarbazone, which forms a blue-violet complex with mercuric ion [24] as in Fig. 2. 


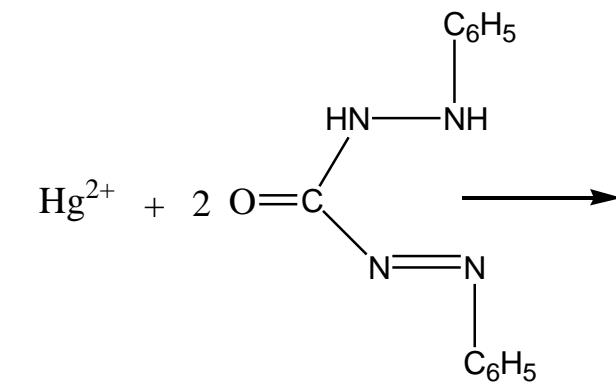

mercuric ion

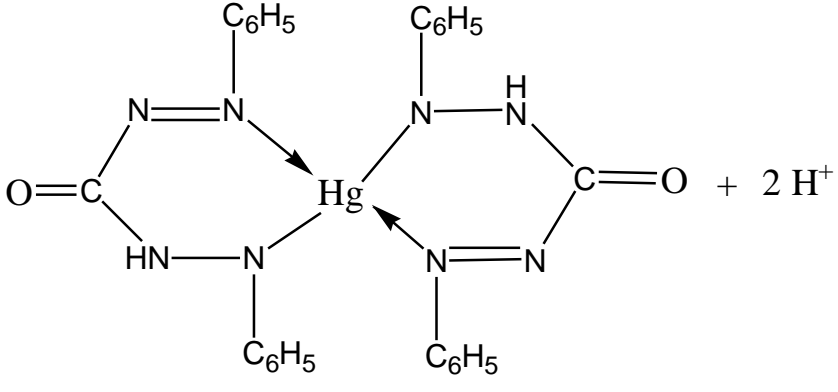

blue-violet complex of

mercuric- diphenylcarbazone
Figure 2. Formation of mercury(II)-diphenylcarbazone complex

Although diphenylcarbazone is a suitable indicator for the titration of chloride with $\mathrm{Hg}^{2+}$ [30] diphenylcarbazone- bromophenol blue mixed indicator was found to give better results as reported by Clarke [31]. Best results were obtained at $\mathrm{pH}$ 3.2-3.4 which was adjusted by adding a requisite amount C $0.05 \mathrm{~mol}^{-1}$. Cla the first decectable change fron its alkaline blue to acid yellow at approximaty $\mathrm{pH}$ 3.6. It therefore can serve the dual purpose of masking premature colour and adjusting $\mathrm{pH}$ [31]. The reaction stoichiometry was calculated to be 2:1 (BUP: $\mathrm{Hg}^{2+}$ ) in the 2-20 $\mathrm{mg}$ range investigated and the quantitative calculations were based on this ratio.

Spectrophotometric method. The spectrophotometric method is based on the reaction of the chloride ion of the drug by a known excess of mercury(II) to form soluble mercuric chloride, and the subsequent determination of the unreacted mercury(II) by interacting with diphenylcarbazone under acidic pH conditions (Fig. 3), and measuring the absorbance at $515 \mathrm{~nm}$ (Fig. 4).

BUP + Known excess of $\mathrm{Hg}^{2+}$ $\mathrm{HgCl}_{2}+$ Unreacted $\mathrm{Hg}^{2+}$

Unreacted $\mathrm{Hg}^{2+}+$ Diphenylcarbazone $\stackrel{\mathrm{H}^{+}}{\longrightarrow}$ Blue violet complex of $\mathrm{Hg}(\mathrm{II})$-Diphenylcarbazone (Absorbance measured at $515 \mathrm{~nm}$ )

Figure 3. Reaction scheme for spectrophotometric method

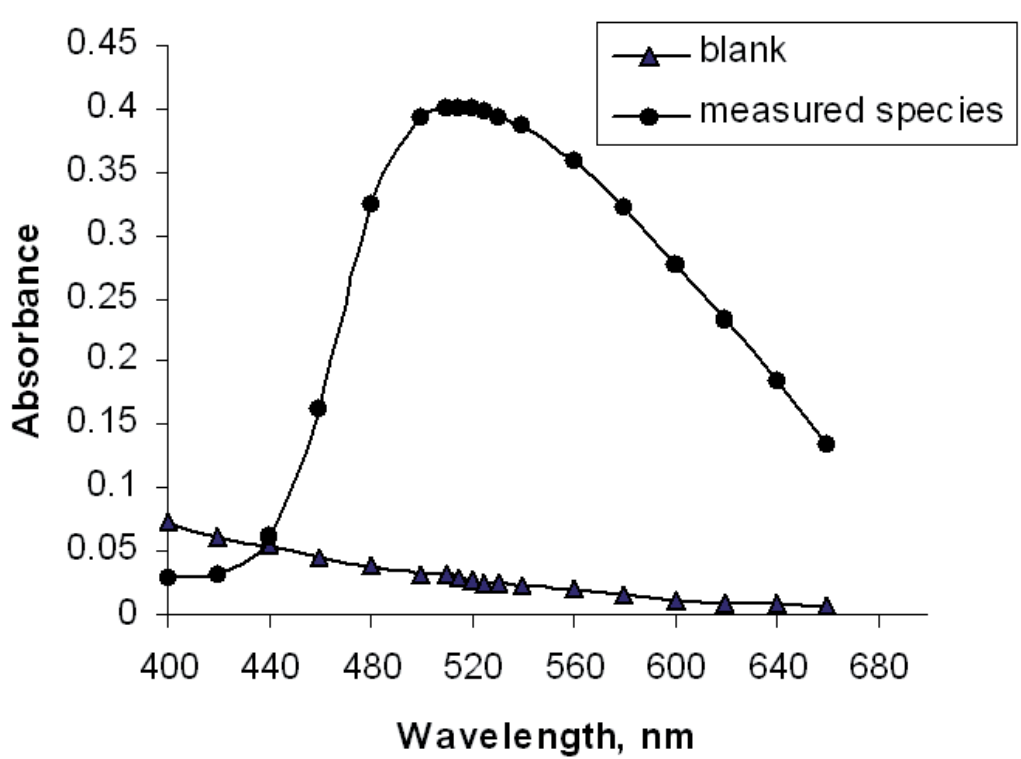

Figure 4. Absorption spectra for mercury(II)-diphenylcarbazone complex in the presence of reaction product (10 $\left.\mu \mathrm{g} \mathrm{mL}^{-1} \mathrm{BUP}\right)$

In this method, the absorbance decreased linearly with increasing concentration of drug. BUP when added in increasing concentrations to fixed concentration of $\mathrm{Hg}(\mathrm{II})$ consumes the latter and there will be a concomitant decrease in the concentration of $\mathrm{Hg}(\mathrm{II})$. When a fixed concentration of diphenylcarbazone is added to decreasing concentration of $\mathrm{Hg}(\mathrm{II})$, a concomitant fall in the concentration of mercury(II)-diphenylcarbazone complex is obtained. This is observed as a proportional decrease in the absorbance of the reaction mixture on increasing the concentration of BUP.

The first step in the spectrophotomic of thod was to evaluate the upper limit of mercury(II) which can be determined using diphenylcarbazone and this was found by treating different amounts of mercury(II) with diphenylcarbazone under the conditions described under the " assay procedures". The study showed that Beer's law is obeyed up to $10 \mu \mathrm{g} \mathrm{mL}{ }^{-1}$ of mercury(II) at room temperature $\left(30^{\circ} \mathrm{C}\right)$. Hence, different amounts of the drug were treated with $2 \mathrm{~mL}^{\circ} 50 \mu \mathrm{mL}^{-1}$ mercury(II) solution and the ungected $\mathrm{ug}^{-1}$ (II) was dersolution following the prodedore described eastier.

Since the various parameters involved in the determination of chloride using the $\mathrm{Hg}(\mathrm{II})$-diphenylcarbazone system are well established [25] the procedure for the determination of BUP was optimized. Since the useful pH range for chloride determination is very narrow (the optimum lies between 3.3 and 3.5), the formate-formic acid buffer of $\mathrm{pH}$ 3.4, which neither complexes mercury nor contains chloride ions, was used, and one $\mathrm{mL}$ of buffer was found optimum for the reaction between the drug and $\mathrm{Hg}(\mathrm{II})$ in a reasonable time of 10 min. A very small a necessary to stabilize the mercury-diphenyca zone complex. The color devepment inbantaneous and the developed color foud to be stathe for and the developed color found to be stable for one hour even in the presence of reaction product, and after that very small particles were found to be formed. 


\section{Method Validation}

Analytical parameters. A linear relation is found between absorbance and concentration of BUP in 1-15 $\mu \mathrm{g} \mathrm{mL}^{-1}$ range, and Beer's law is obeyed in the reverse manner; the equation of the line being $\mathrm{Y}=0.6588+(-0.0331) \mathrm{X}$

where $\mathrm{Y}$ is the absorbance and $\mathrm{X}$ is concentration in $\mu \mathrm{g} \mathrm{mL} \mathrm{L}^{-1}$. The correlation coefficient (r) of the calibration plot is calculated to be $(-0.9996)$ confirming a linear decrease in absorbance with increasing the concentration. The molar absorptivity is calculated to be $8.6 \times 10^{3} \mathrm{~L} \mathrm{~mol}^{-1} \mathrm{~cm}^{-1}$, and Sandell sensitivity being $0.0321 \mu \mathrm{g} \mathrm{cm}^{-2}$. The limits of detection (LOD) and quantification (LOQ) are calculated to be 0.33 and $1.00 \mu \mathrm{gL}^{-1}$, respectively.

Accuracy and precision. The accuracy of an analytical method expresses the closeness between the reference value and the found value [32] Accuracy was evaluated as percentage relative error between the measured concentrations and taken concentrations for BUP (Bias \%). The results obtained are compiled in Table 1 and showed that the accuracy is good for both methods. The precision of the methods was calculated in terms of intermediate precision (intra-day and inter-day) [33]. Three differen (intra-day precision) and five consecutive days (inter-day precision). The RSD (\%) values of intra-day and inter-day studies showed that the precision was good for both methods (Table 1).

Table 1. Evaluation of intra-day and inter-day precision and accuracy

\begin{tabular}{|c|c|c|c|c|c|c|c|}
\hline \multirow[t]{2}{*}{ Method* } & \multirow[t]{2}{*}{$\begin{array}{l}\text { BUP } \\
\text { taken }\end{array}$} & \multicolumn{3}{|c|}{ Intra-day (n=7) } & \multicolumn{3}{|c|}{$\begin{array}{c}\text { Inter-day } \\
\text { Inter-day (n=5) }\end{array}$} \\
\hline & & $\begin{array}{c}\text { BUP } \\
\text { founda }\end{array}$ & Precisionb & Accuracyc & $\begin{array}{c}\text { BUP } \\
\text { founda }\end{array}$ & Precisionb & Accuracyc \\
\hline \multirow{3}{*}{ Titrimetric method } & $\begin{array}{l}5.00 \\
10.0\end{array}$ & 4.95 & 1.54 & 1.00 & 5.06 & 2.24 & 1.20 \\
\hline & 10.0 & 9.91 & 0.63 & 0.90 & 10.11 & 1.68 & 1.10 \\
\hline & & 14.89 & 0.66 & 0.73 & 15.20 & 1.39 & 1.33 \\
\hline \multirow{3}{*}{$\begin{array}{l}\text { Spectrophotometric } \\
\text { method }\end{array}$} & 4.0 & 3.94 & 2.74 & $\begin{array}{l}1.50 \\
3.12\end{array}$ & 4.09 & 3.15 & 2.25 \\
\hline & 8.0 & 7.75 & 2.25 & 3.12 & 8.14 & 2.86 & 1.75 \\
\hline & 12.0 & 11.91 & 1.24 & & 12.26 & 2.32 & 2.17 \\
\hline
\end{tabular}

*BUPtaken/found in titrimetric method is in mg and the same in spectrophotometric method is in $\mu \mathrm{gmL}^{-1}$, a. Mean \pm standard error, b. Relative standard deviation (\%), c. Relative Error (\%)

Selectivity. To determine the selectivity of the methods, the analytical placebo was prepared and subjected to analysis by the proposed methods. It was confirmed that the change in the titrant value and absorbance with respect to the water blank was caused only by the analyte. To identify the interference by common tablet excipients, a synthetic mixture with the composition: BUP $(200 \mathrm{mg})$, talc $(80 \mathrm{mg})$, starch $(160 \mathrm{mg})$, calcium gluconate $(80 \mathrm{mg})$, lactose $(80 \mathrm{mg})$, sodium alginate $(40 \mathrm{mg})$ and magnesium stearate $(40 \mathrm{mg}$ ), was prepared and subjected to analysis by the proposed methods after solution preparation using the procedure described for tablets. The percent recoveries of BUP were $101.20 \pm 0.83$ ( $=5)$ and $103.50 \pm 1.49(\mathrm{n}=5)$ by titrimetry and spectrophotometry, respectively, suggesting no interference by the excipients in the assay of BUP under the described optimum conditions.

Application to formulations. The proposed methods were successfully applied to the determination of BUP in two representative tablets bupron-SR-150 and ession-ER-150. The results obtained are shown in Table 2 and were compared with those obtained by the official method [20] by means of student's t- and F-tests at $95 \%$ confidence level. The official method involves the visual titration of the drug with acetous perchloric acid in non aqueous medium using crystal violet indicator. In all cases, the average results obtained by the proposed methods and official method were statistically identical, as the difference between the average values had no significance at $95 \%$ confidence level with respect to accuracy and precision.

Table 2. Comparison of assay results by proposed and official methods

\begin{tabular}{|c|c|c|c|c|}
\hline \multirow{3}{*}{$\begin{array}{l}\text { Tablet } \\
\text { brand } \\
\text { Name }\end{array}$} & \multirow{3}{*}{$\begin{array}{l}\text { Nominal } \\
\text { amount, mg }\end{array}$} & \multicolumn{3}{|c|}{ Found (\% of nominal amount $\pm \mathrm{SD}$ )* } \\
\hline & & Official method & & osed methods \\
\hline & & & Titrimetric method & Spectrophotometric method \\
\hline $\begin{array}{l}\text { Bupron } \\
\text { SR 150 }\end{array}$ & 150 & $97.65 \pm 0.72$ & $\begin{array}{c}98.33 \pm 1.26 \\
t=1.08 \\
F=3.06\end{array}$ & $\begin{array}{c}97.94 \pm 1.43 \\
t=0.43 \\
F=3.94\end{array}$ \\
\hline $\begin{array}{l}\text { Ession } \\
\text { ER } 150\end{array}$ & 150 & $100.3 \pm 0.64$ & $\begin{array}{c}101.4 \pm 1.35 \\
t=1.75 \\
F=4.45\end{array}$ & $\begin{array}{c}99.68 \pm 1.48 \\
t=0.92 \\
F=5.35\end{array}$ \\
\hline
\end{tabular}

*Mean value of five determinations,

Tabulated t-value at the 95\% confidence level is 2.78; Tabulated F-value at the 95\% confidence level is 6.39

Recovery Study. To ascertain the accuracy and validity of the proposed methods, recovery experiment was performed via standard addition technique. To a fixed and known amount of BUP in tablet powder (pre-analysed), pure drug was added at three levels (50,100 and $150 \%$ of the level present in the tablet) and the total was found by the proposed methods. Results of this study presented in Table 3 indicate that the commonly added excipients such as talc, starch, lactose, sodium alginate, magnesium indicate that the commonly added excipients such as talc, starch, lactose, sodium alginate, magnesiun
stearate, calcium gluconate and calcium dihydrogen orthophosphate did not interfere in the assay.

Table 3. Results of recovery study by standard-addition method

\begin{tabular}{|c|c|c|c|c|c|c|c|c|}
\hline \multirow[b]{2}{*}{$\begin{array}{l}\text { Formulation } \\
\text { studied }\end{array}$} & \multicolumn{4}{|c|}{ Titrimetric method } & \multicolumn{4}{|c|}{ Spectrophotometric method } \\
\hline & $\begin{array}{l}\text { BUP in } \\
\text { tablet, mg }\end{array}$ & $\begin{array}{c}\text { Pure } \\
\text { BuPadded, } \\
\text { mg }\end{array}$ & $\begin{array}{l}\text { Total found, } \\
\text { mg }\end{array}$ & $\begin{array}{l}\text { Pure BUP } \\
\text { recovered*, } \\
\text { Percent } \pm S D\end{array}$ & $\begin{array}{l}\text { BUP in } \\
\text { tablet, } \mu \mathrm{g} \\
\text { mL-1 }\end{array}$ & $\begin{array}{l}\text { Pure BUP } \\
\text { added, } \mu \mathrm{g} \\
\text { mL-1 }\end{array}$ & $\begin{array}{c}\text { Total } \\
\text { found, } \\
\mu \mathrm{g} \mathrm{mL-1}\end{array}$ & $\begin{array}{l}\text { Pure BUP } \\
\text { recovered*, } \\
\text { Percent } \pm \text { SD }\end{array}$ \\
\hline \multirow{3}{*}{$\begin{array}{l}\text { Bupron } \\
\text { SR } 150\end{array}$} & 7.87 & 4.0 & 11.89 & $100.50 \pm 2.51$ & 4.90 & 2.5 & 7.37 & $98.80 \pm 1.93$ \\
\hline & 7.87 & 8.0 & 16.02 & $101.88 \pm 0.87$ & 4.90 & 5.0 & 9.75 & $97.00 \pm 2.08$ \\
\hline & 7.87 & 12.0 & 20.10 & $101.92 \pm 1.02$ & 4.90 & 7.5 & 12.26 & $98.13 \pm 1.65$ \\
\hline \multirow{3}{*}{$\begin{array}{c}\text { Ession } \\
\text { ER } 150\end{array}$} & 8.11 & 4.0 & 12.18 & $101.75 \pm 2.31$ & 4.98 & 2.5 & 7.46 & $99.20 \pm 2.06$ \\
\hline & 8.11 & 8.0 & 16.09 & $99.75 \pm 1.08$ & 4.98 & 5.0 & 10.24 & $105.20 \pm 2.05$ \\
\hline & 8.11 & 12.0 & 20.20 & $100.75 \pm 0.81$ & 4.98 & 7.5 & 12.68 & $102.67 \pm 1.44$ \\
\hline
\end{tabular}

*Mean value of three determinations 


\section{Conclusions}

Two useful methods for the determination of BUP have been developed and validated. The assay results demonstrate that it is possible to use mercury(II) nitrate, which is stable enough and need no special precautions during storage or use, as a reagent for determination of BUP in authentic samples. The only titrimetric method currently available [20] uses non aqueous medium. The proposed titrimetric method is simple, rapid, free from critical experimental variables, uses aqueous medium and applicable over a wide range (2-20 $\mathrm{mg}$ ). The spectrophotometric method is the first visible spectrophotometric method for determination of BUP and it is free from the usual analytical complications like heating and extraction. Moreover, the methods are accurate, reproducible, adequately sensitive and free from interference by common additives and excipients. The wide applicability of the new procedures for routine quality control is well established by the assay of BUP in pure form and in pharmaceutical preparations.

\section{Acknowledgements}

One of the authors (MASA) wishes to express his thanks to Thamar University, Republic of Yemen for awarding research fellowship and two of the authors (MASA and KBV) thank the authorities of the University of Mysore for permission and facilities to carryout the research work.

\section{References}

[1] The Merck Index: An Encyclopedia of Chemicals, Drugs, and Biologicals, Merck \& Co., Inc., Whitehouse Station, New Jersey, USA, 14 th edn., 2006, p. 246.

[2] D.H. Schroeder, J. Clin. Psychiatry 44 (1983) 79.

[3] S.G. Bryant, B.G. Guernsey, N.B. Ingrim, Clin. Pharm. 2 (1983) 525.

[4] R.M. Lane, G.B. Baker, Cell. Mol. Neurobiol. 19 (1999) 355.

[5] H.G. Kinnell, Br. J. Clin. Pharmacol. 322 (2001) 431.

[6] A.J. Johnston, J. Ascher, R. Leadbetter, V.D. Schmith, D.K. Patel, M. Durcan, B. Bentley, Drugs 62 (2002) 11.
[7] K. K. Loboz , A. S. Gross , J. Ray, A. J. McLachlan, J. Chromatogr. B, 823 (2005) 115.

[8] K. I. Al-khamis, J. Liq. Chrom. Relat. Tech. 12 (1989) 645.

[9] D.H. Schroeder, M.L. Hinton, P.G. Smith, C.A. Nichol, R.M. Welch, Fed. Proc. Fed. Am. Soc. Exp. Biol. 37 (1978) 691.

[10] T.A. Jennison, P. Brown, J. Crossett, F.M. Urry, J. Anal. Toxicol. 19 (1995) 69.

[11] D. Zhang, B. Yuan, M. Qiao, F. Li, J. Pharm. Biomed. Anal. 33 (2003) 287.

[12] R.F. Butz, D.H. Schroeder, R.M. Welch, N.B. Mehta, A.P. Phillips, J.W.A. Findlay, J. Pharm. Exp. Ther. 217 (1981) 602.

[13] T.P. Rohrig, N.G. Ray, J. Anal. Toxicol. 16 (1992) 343.

[14] T.B. Cooper, R.F. Suckow, A. Glassman, J. Pharm. Sci. 73 (1984) 1104.

[15] R.F. Suckow, M.F. Zhang, T.B. Cooper, Biomed. Chromatogr. 11 (1997) 174.

[16] M. M. Schultz, E. T. Furlong, Anal. Chem. 80 (2008) 1756.

[17] C. Arellano, C. Philibert, C. Vachoux, J. Woodley, G. Houin, J. Chromatogr. B, 829 (2005) 50.

[18] R. Coles, E. D. Kharasch, J. Chromatogr. B, 857 (2007) 67.

[19] V. Borges , E.Yang , J. Dunn, J. Henion, J. Chromatogr. B, 804 (2004) 277.

[20] L. Delazzeri, Caderno de Farmácia, 21 (2005) 37.

[21] Q. Meiling1 , W. Peng , G. Yingshu , G. Junling1 and F. Ruonong1, J. Chin. Pharmaceut. Sci., 11(2002)16.

[22] L. Delazzeri, S.B. Borba, A.M. Bergold, Rev. Ciênc. Farm. Básica Apl., 26 (2005) 211.

[23] R. T. Sane, M. Francis, S. Khedkar, A. Menezrs, A. Moghe, P. Patil, Indian drugs, 40 (2003) 231.

[24] A.I. Vogel, A Text-Book of Quantitative Inorganic Analysis, Longman Group Limited, London, $3^{\text {rd }}$ edn., 1961, p. 274.

[25] W. Kemula, A. Hulanicki, A. Janowski, Talanta 7 (1960) 65.

[26] C.H. Wilkinson, R. Cole, J. Hosp. Pharm. 26 (1969) 45.

[27] D. Zhou, W. He, Yaoxue Jangbao 20 (1985) 662.

[28] K. Basavaiah and V. S. Charan, IL Farmaco 57 (2002) 9.

[29] Z. Malkova, J. Novak, Chem. Listy. 86 (1992) 464.

[30] R.A. Day Jr., A.L. Underwood, Quantitative Analysis, Prentice-Hall of India Private Ltd, New Delhi, $6^{\text {th }}$ edn., 2005, pp. 221.

[31] F.E. Clarke, Anal. Chem. 22 (1950) 553.

[32] International Conference on Hormonisation of Technical Requirements for Registration of Pharmaceuticals for Human Use, ICH Harmonised Tripartite Guideline, Validation of Analytical Procedures: Text and Methodology Q2(R 1), Complementary Guideline on Methodology dated 06 November 1996, incorporated in November 2005, London. [33] G. A. Shabir, J. Chromatogr. A, 987 (2003) 57. 